\title{
INVESTIGATION OF THE INFLUENCE OF THE ROSEMARY EXTRACT ON THE OXIDIZING STABILITY OF FATS OF SEMI-SMOKED SAUSAGES WITH PEKING DUCK MEAT
}

\author{
Nataliia Bozhko \\ Department of Biophysics, Biochemistry, Pharmacology and Biomolecular Engineering \\ Medical Institute \\ 31 Sanatornaya str., Sumy, Ukraine, 40018 \\ Sumy State University \\ 2 Rymskoho-Korsakova str., Sumy,Ukraine, 40007 \\ natalybozhko@ukr.net \\ Vasyl Pasichnyi \\ Department of Technology of Meat and Meat Products \\ Pasww1@ukr.net \\ Andriy Marynin \\ Problem Research Laboratory ${ }^{1}$ \\ andrii_marynin@ukr.net \\ Vasyl Tischenko \\ Department of Technology of Milk and Meat ${ }^{2}$ \\ tischenko_1958@ukr.net \\ Igor Strashynskyi \\ Department of Technology of Meat and Meat Products ${ }^{1}$ \\ sim2407@i.ua \\ Oleksandr Kyselov \\ Department of Biochemistry and Biotechnology ${ }^{2}$ \\ oleksandr.kyselov@snau.edu.ua \\ ${ }^{1}$ National University of Food Technologies \\ 68 Volodymyrska str., Kyiv, Ukraine, 01601 \\ ${ }^{2}$ Sumy National Agrarian University \\ 160 H. Kondratieva str., Sumy, Ukraine, 40021
}

\section{Abstract}

The work is devoted to studying the fatty-acid composition and biological efficiency of a developed meat-containing semismoked sausage, based on duck meat with the balanced fatty-acid composition, investigating the effectiveness of using a rosemary extract in a technology of sausages with a high content of unsaturated fatty acids. It is confirmed, that the fatty-acid composition of meat-containing semi-smoked sausage of Peking duck is characterized by the optimal ratio of PUFA and SFA that is 0.33 , at standard 0.2-0.4. The ratio between FA families $\omega-3 / \omega-6$ in the developed products is from 1:11 at recommended physiological norms of the ideal composition of lipids in a meat product as 1:10.

Introduction of the rosemary extract in amount $0.02-0.06 \%$ of the forcemeat mass decelerates hydrolytic oxidation of forcemeat lipids, favors deceleration of peroxide oxidation of lipids in a meat-containing semi-smoked sausage, decreasing the amount of peroxides in practically five times. The positive influence of the introduced antioxidant on accumulation of secondary oxidation products is noticed. Their summary amount was the least at the end of the storage term of ready products with the rosemary extract as $0.38-0.80 \mathrm{mg}$ of MA/ $\mathrm{kg}$ of the product that is $2.54-3.94$ times lower than in a control sample. The most stabilizing effect on the process of lipids oxidation is obtained at introducing the rosemary extract in amount $0.06 \%$ that allows to decrease the speed of oxidation processes in the product almost twice.

Keywords: meat-containing semi-smoked sausage, duck meat, unsaturated fatty acids, rosemary extract. 


\section{Introduction}

Healthy nutrition is impossible without protein of animal origin, which source is meat and meat products [1]. Nutrients of meat products provide humans with necessary means of growth and development, support of healthy condition and effective functioning of the immune system. Deficiency or low content of separate components, for example, such as unsaturated fatty acids may result in the development of internal alimentary diseases, "non-contagious illnesses", including coronary heart disease $[2,3]$. In this connection an urgent task for meat industry is for today to develop and to implement new meat-containing products with a balanced fatty-acid composition.

\section{Problem condition review}

The fatty-acid composition of most types of meat is mainly presented by saturated fatty acids [4], monounsaturated [5] and polyunsaturated ones that are essential and realize a series of important functions in the human organism $[6,7]$.

The negative effect of excessive consumption of saturated fatty acids is known $[8,9]$, and the positive one of polyunsaturated fatty acid consumption on the ratio of blood plasma lipoproteins is proved [10]. In this connection WHO recommends [11] the formula of the ideal lipid nutrition as $10 \%$ of SFA and $6-10 \%$ of USFA a day at $30 \%$ of fat of the total caloric value in the human ration.

At consuming such meat types as pork and beef, it is impossible to achieve the ideal ratio between PUFA and SFA, which optimal diapason is from 0.2 to $0.4[12,13]$. But the meat of water birds, namely duck, allows to optimize the fatty-acid composition of a meat product [14]. The balance of fatty acids in the composition of a meat-containing product may be achieved either forming the food value of bird meat at the expanse of a breeding technology or introducing additional sources of essential fatty acids to the product composition $[15,16]$.

Connected with an increased risk of oxidation of enriched products, there appears a necessity of using antioxidant systems that would allow to decelerate oxidizing spoilage of complicated meat-containing systems with a prolonged storage term [17-20]. There is an ecological method of meat enrichment with anti-oxidizing inhibitors at breeding through feeding, but its defect is instability of the concentration of active substances in certain forage types [21-23]. Most progressive methods are the use of modified packages, covered with vegetable extracts $[24,25]$ or special gas mediums [26]. But the most spread way of inhibiting lipids oxidation in meat and meat-containing products is to use antioxidants, both synthetic [27, 28], and natural [29-31]. A technology of using antioxidants with a high concentration of phenol compounds is especially effective [32, 33].

That is why the main aim of our studies is to investigate the fatty-acid composition and biological efficiency of a developed meat-containing semi-smoked sausage, based on duck meat with the balanced fatty-acid composition. One of tasks is also to investigate the effectiveness of using the rosemary extract in a technology of sausages with a high content of unsaturated fatty acids.

\section{Materials and methods}

A semi-smoked sausage was produced by [34] technology for the research. The recipe included crumbled Peking duck meat, with-free pork heart, side lard, chicken skin, comminuted on a roll with diameter of grating orifices 16-25 mm. Forcemeat was added with dry whey, soya isolate, preliminarily hydrated 1:4 by drinking water, vegetable cellulose preparation fiber 110. All ingredients were mixed, the forcemeat was added with salt and spices. After filling a natural coat with the ready forcemeat, ready sausages were put down at temperature $4-8{ }^{\circ} \mathrm{C}$ during 2 hours. Then they were dried and fried at temperature $90^{\circ} \mathrm{C}$ during one hour, cooled and boiled at $40 \ldots 50 \mathrm{~min}$. After cooling at $t<20^{\circ} \mathrm{C}$, during 2 hours the sausages were smoked at $t=(43 \pm 7){ }^{\circ} \mathrm{C}, \tau=12 \ldots .24$ hours. After smoking they were dried at $t=10 \ldots 12^{\circ} \mathrm{C}$ and relative humidity $76.5 \pm 1.5 \%$ during one hour. After finishing the technological process, the sausage was stored at temperature no higher $12{ }^{\circ} \mathrm{C}$ during 20 days.

The rosemary extract (Food Ingredients Mega Trade, USA) was used for the experiment with natural antioxidants (Fig. 1).

At producing forcemeat of the semi-smoked sausage, the rosemary extract (RE) was added by the following scheme: No. 1 - RE 0,02\%; No. 2 - RE 0,04 \%; No. 3 - RE $0.06 \%$ of the raw material mass. A sample without adding antioxidants was used as a control. 


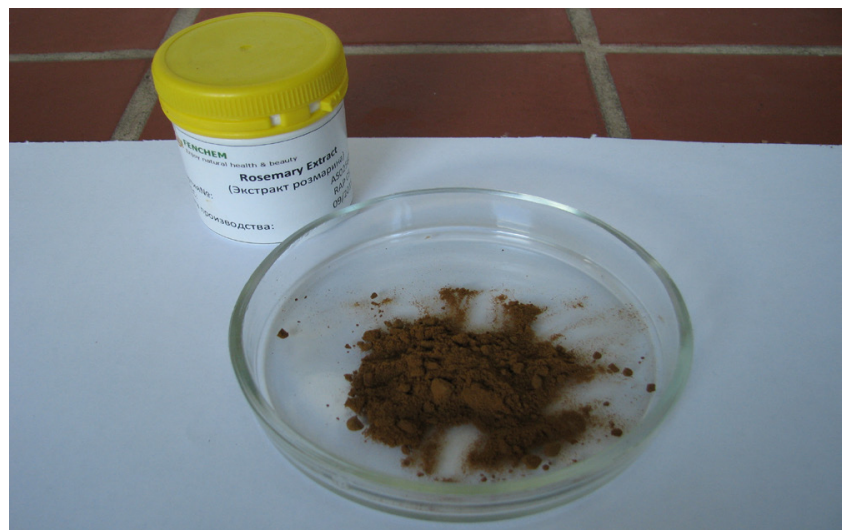

Fig. 1. Rosemary extract

Determination of the fatty-acid of the semi-smoked sausages was carried out by the method of gas-liquid chromatography, using the automated gas chromatograph Kupol-55 [35]. For determining the fatty-acid composition of the sausages, a sample was prepared by lipids extraction. The extracts was concentrated on the rotor evaporator at temperature no higher $40{ }^{\circ} \mathrm{C}$. After heating on the water bath during $50 \mathrm{~min}$, the extract was dissolved by water in ratio 1:1. The hexane extracts were obtained. Hexane was steamed on the rotor evaporator, chromatographically pure methyl esters of fatty acids were obtained, solved in hexane and chromatographed on the chromatograph Kupol-55 (Russia) on the column SP 2560 (USA) with length 100 m (Fig. 2).

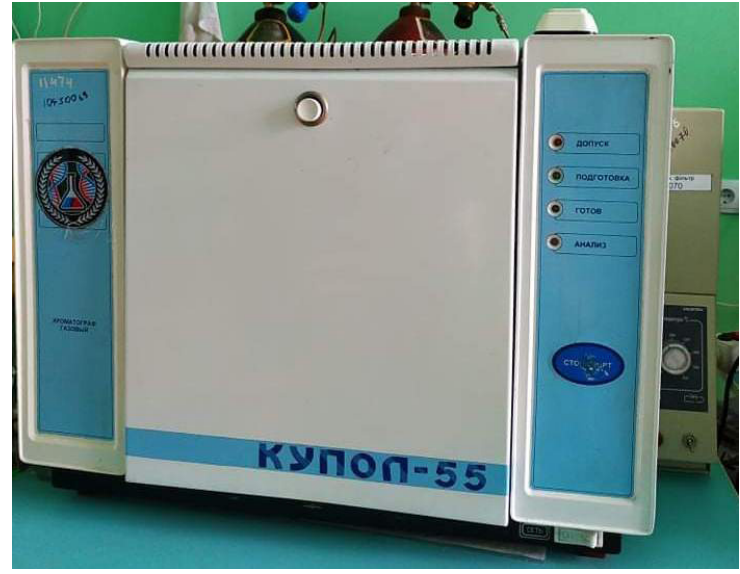

Fig. 2. Chromatograph Kupol-55 (Russia)

The acid number was determined by titration of a batch by sodium hydroxide in the concentration at presence of the phenolphthalein alcohol solution [36]. 3-5 g of the studied forcemeat were weighed in a conic flask of $150-200 \mathrm{~cm}^{3}$ with an error, no more $0.001 \mathrm{~g}$. The batch was heated on the water bath, added with $50 \mathrm{~cm}^{3}$ of the neutralized ester-alcohol mixture and shaken. Then 3-5 drops of the alcohol solution of phenolphthalein with the mass share $1 \%$ were added. The obtained solution at continuous shaking was fast titrated by the potassium hydroxide solution of molar concentration $0.1 \mathrm{~mol} / \mathrm{dm}^{3}$ to the clear pink coloration that doesn't disappear during $1 \mathrm{~min}$. The acid number was calculated by the formula:

$$
X=(V \times K \times 5.61) / m,
$$

where $V$ - volume of potassium hydroxide solution of molar concentration $0.1 \mathrm{~mol} / \mathrm{dm}^{3}$, spent for titration; $K$ - correction for the alkaline solution for recalculation for the distinct $\left(0.1 \mathrm{~mol} / \mathrm{dm}^{3}\right)$ solution; 5.61 - amount of milligrams of potassium hydroxide, contained in $1 \mathrm{~cm}^{3}\left(0.1 \mathrm{~mol} / \mathrm{dm}^{3}\right)$ of the solution; $m$ - mass of the forcemeat batch, $g$. 
The method of PN determination is based on extraction of the batch by the chloroform mixture and ice acetic acid and further titration by the sodium hyposulfite solution with the previously added starch solution [36].

$0.8-1 \mathrm{~g}$ of the batch, weighted with distinctness no more $0,0002 \mathrm{~g}$ were put in a conic flask with a closed cork, melt of the water bath and $10 \mathrm{~cm}^{3}$ of chloroform and $10 \mathrm{~cm}^{3}$ of ice acetic acid were poured by the flask wall. $0.5 \mathrm{~cm}^{3}$ of the saturated new-prepared potassium iodide solution was fast added. The flask was closed by a cork, the content was mixed by rotation movements and put in a dark place for $3 \mathrm{~min}$. After keeping, the flask was added with $100 \mathrm{~cm}^{3}$ of distilled water, previously added with $1 \mathrm{~cm}^{3}$ of the starch solution with mass share $1 \%$. Then it was titrated by the sodium hyposulfite solution with molar concentration $0.01 \mathrm{~mol} / \mathrm{dm}^{3}$ to blue coloration disappearing.

For checking pureness of reagents, the control determination without a batch was conducted. The peroxide number was calculated by the formula:

$$
X=\left(V-V_{1}\right) \times K \times 0.00127 \times 100 / m,
$$

where $V$ - volume of the sodium hyposulfite solution of molar concentration $0.01 \mathrm{~mol} / \mathrm{dm}^{3}$, spent for titration at conducting the main experiment with the forcemeat batch, $\mathrm{cm}^{3} ; V_{1}-$ volume $\left(0.01 \mathrm{~mol} / \mathrm{dm}^{3}\right)$ of the sodium hyposulfite solution, spent for titration at conducting the control experiment (without the forcemeat batch), $\mathrm{cm}^{3} ; \mathrm{K}$ - error coefficient to the hyposulfite sodium solution for recalculation for the distinct $\left(0.01 \mathrm{~mol} / \mathrm{dm}^{3}\right)$ solution; 0.00127 - number of iodine grams, equivalent $1 \mathrm{~cm}^{3}$ $\left(0.01 \mathrm{~mol} / \mathrm{dm}^{3}\right)$ of the sodium hyposulfite iodine; $m$ - batch mass of the studied forcemeat, $\mathrm{g}$.

TBN determination was conducted by measuring the intensity of distillate mixture coloration of the studied sample with the thiobarbituric acid solution (1:1) after keeping on the water bath during 35 minutes on the spectrophotocolorimeter «Speкоl-11» (Germany) at wave length 535 nm [36] (Fig. 3).

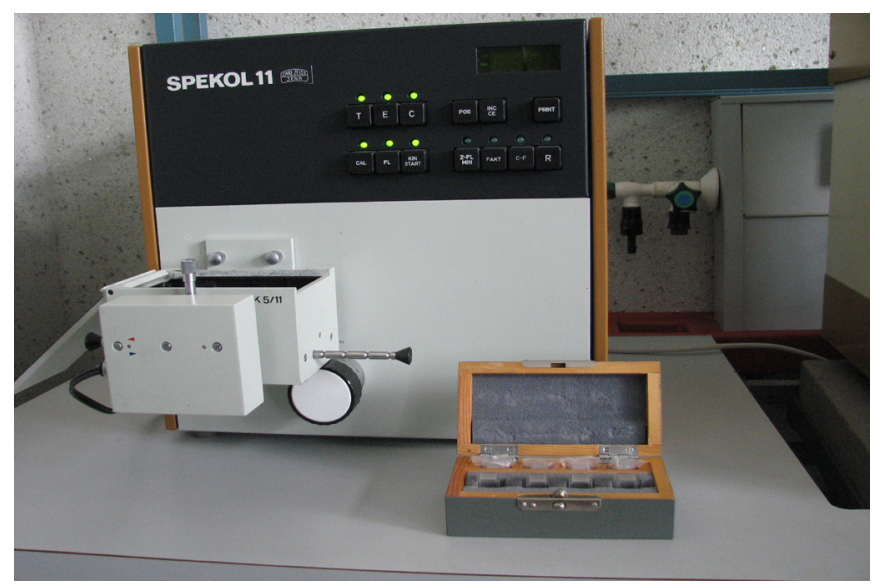

Fig. 3. Spectrophotocolorimter «Spekol-11» (Germany)

$50 \mathrm{~g}$ of the forcemeat batch were added to a porcelain pounder, $50 \mathrm{~cm}^{3}$ of distilled water were measured by a glass cylinder, introduced in the pounder, and the mixture was rubbed by a pestle to the homogenous condition. The prepared test was quantitatively transferred to the Kjeldahl flask, washing residues from the flask by $47.5 \mathrm{~cm}^{3}$ of distilled water, and added with $2.5 \mathrm{~cm}^{3}$ hydrochloric acid. Distillation was conducted in the Kjeldahl apparatus, collecting $50 \mathrm{~cm}^{3}$ of the distillate to the measuring flask. $5 \mathrm{~cm}^{3}$ of the distillate were taken, introduced to the flask with the rubbed cork, $5 \mathrm{~cm}^{3}$ of thiobarbituric acid were added, mixed and put on the boiling water bath for $35 \mathrm{~min}$, fixing time by a stopwatch.

At the same time a control sample was conducted, using $5 \mathrm{~cm}^{3}$ of distilled water instead of distillate. Then the solutions were cooled in running cold water during $10 \mathrm{~min}$, fixing time by the stopwatch, and the optic density was measured at wave length $(535 \pm 10) \mathrm{nm}$ as to the control solution. 
The thiobarbituric number, mg MA (malonic aldehyde)/kg of the product was calculated by the formula:

$$
X=D \times 7.8
$$

where $D$ - optic density of the solution; 7.8 - coefficient of proportional dependence of MA density on its concentration in the solution. This coefficient is a constant value.

The absolute error of measurements was determined by Student's criterion, reliable interval $P=0.95$, number of iterations in determinations 3-4, number of parallel tests of experimental samples -3 .

\section{Results}

As a result of the analysis of the fatty acid composition of the meat-containing semi-smoked sausage, it has been established, that the ratio between saturated and unsaturated fatty acids in the sample of the developed sausage was $0.33(14.74 / 44.34)$ that corresponds to the norm [11]. At that SFA concentration in the sausage was $44.34 \%$ in fat of the product, main of them were palmitic $(25.36 \mathrm{~g} / 100 \mathrm{of}$ fat) and stearic (14.61 g/100 g of fat) fatty acids. On the other side, the mass share of PUSA was $14.24 \mathrm{~g} / 100 \mathrm{~g}$ of fat and differed by the high content of $\omega-6$ linoleic acid (13.40 g/100 g). In the composition of fat of the sausage there was revealed $\omega-3 \alpha$-linolenic acid, which concentration in the product fat is $1.22 \mathrm{~g} / 100 \mathrm{~g}$.

Among different varieties of birds, just duck differs by the skeleton muscular system with a higher level of lipids and concentration of polyunsaturated fatty acids that, in their turn, influence the intensity and saturation of the meat smell [37-40]. So, the use of duck meat in recipes of meat-containing products is effective in the aspect of creation of a product, balanced by the fattyacid composition. The study of the individual fatty acids concentration has demonstrated that the product contains not only cis-isomers of separate fatty acids, but also their trans-modifications. Thus, $0.57 \%$ of trans-oleic acid were revealed in the product, but it corresponds to data [41] and is not a risk factor for the human health [42-44].

As a result of using duck meat in the recipe, the biologic effectiveness of lipids of the meat-containing semi-smoked sausage, characterized by the standard ratio of $\omega-3$ and $\omega-6$ SUFA [45], is 1:11.

At studying the effectiveness of using the rosemary extract, it has been established, that the preparation decelerates hydrolysis of fats in systems with the high content of unsaturated fatty acids. It is explained by the high concentration of flavonoids of the extract, confirmed by the studies of the rosemary extract influence on oxidizing processes in a technology of beef cutlets [46-48]. The study of the dynamics of peroxide oxidation in the samples has demonstrated that PN in the control sample of sausage grew at the storage term from $0.15 \pm 0.01$ to $0.65 \pm 0.00 \mathrm{~J} \%$. In the experimental samples of semi-smoked sausage, $\mathrm{PN}$ at the end of the storage term varied from $0.11 \pm 0,001 \mathrm{~J} \%$ in sample 2 to $0.16 \pm 0,002 \mathrm{~J} \%$ in sample 1 .

The rosemary extract had the most effect in concentration $0.06 \%$ of the raw material mass. Thus at the end of the storage term the correspondent sample of semi-smoked sausage had the peroxide number $1.65 \pm 0.07 \mathrm{mg} \mathrm{KOH}$, whereas in the control $\mathrm{CN}$ was $2.54 \pm 0.49 \mathrm{mg} \mathrm{KOH}$ that is by $53,94 \%$ higher.

As a result of decelerating peroxide oxidation of sausage lipids, the concentration of secondary products of lipids oxidation (pentanal, hexanal, malonic aldehyde and other) was decreased in average 3 times that is confirmed by the TBN value. At the storage end TBN of the experimental samples varied at level $0.38-0.80 \mathrm{mg}$ of $\mathrm{MA} / \mathrm{kg}$ of the product that is $2.54-3.94$ times lower comparing with the control.

\section{Conclusions}

It is confirmed, that the fatty-acid composition of meat-containing semi-smoked sausage of Peking duck is characterized by the optimal ratio of PUFA and SFA that is 0.33, at standard 0.2-0.4. 
The ratio between FA families $\omega-3 / \omega-6$ in the developed products is from 1:11 at recommended physiological norms of the ideal composition of lipids in a meat product as 1:10.

The high effectiveness of the rosemary extract in decelerating the lipids oxidation process in meat-containing products is confirmed. Introduction of the rosemary extract in amount $0.02-0.06 \%$ of the forcemeat mass decreases the concentration of free fatty acids by $53.94 \%$, favors deceleration of peroxide oxidation of lipids in the meat-containing semi-smoked sausage, decreasing the amount of peroxides in practically five times, comparing with the control. The positive influence of the introduced antioxidant on accumulation of secondary oxidation products is noticed. TBN was the least at the end of the storage term of the ready products with the rosemary extract and was $0.38-0.80 \mathrm{mg}$ of $\mathrm{MA} / \mathrm{kg}$ of the product that is 2.54-3.94 times lower than in the control sample.

The optimal RE concentration for decelerating oxidizing processes in the semi-smoked sausage of Peking duck meat has been determined. The most stabilizing effect is obtained at introducing the rosemary extract in amount $0.06 \%$ of the raw material mass that allows to decrease the speed of oxidizing processes in the product almost twice.

\section{References}

[1] Wood, J., Enser, M., Whittington, F., Richardson, R. (2007). Fatty Acids in Meat and Meat Products. Food Science and Technology, 87-107. doi: https://doi.org/10.1201/9781420006902.ch5

[2] Wood, J. D., Enser, M. (2017). Manipulating the Fatty Acid Composition of Meat to Improve Nutritional Value and Meat Quality. New Aspects of Meat Quality, 501-535. doi: https://doi.org/10.1016/b978-0-08-100593-4.00023-0

[3] Innes, J. K., Calder, P. C. (2020). Marine Omega-3 (N-3) Fatty Acids for Cardiovascular Health: An Update for 2020. International Journal of molecular Sciences, 21 (4), 1362. doi: https://doi.org/10.3390/ijms21041362

[4] Lisitsyn, A. B., Chernukha, I. M., Lunina, O. I. (2017). Fatty acid composition of meat from various animal species and the role of technological factors in trans-isomerization of fatty acids. Foods and Raw Materials, 5 (2), 54-61. doi: https://doi.org/ 10.21603/2308-4057-2017-2-54-61

[5] Mapiye, C., Aldai, N., Turner, T. D., Aalhus, J. L., Rolland, D. C., Kramer, J. K. G., Dugan, M. E. R. (2012). The labile lipid fraction of meat: From perceived disease and waste to health and opportunity. Meat Science, 92 (3), 210-220. doi: https:// doi.org/10.1016/j.meatsci.2012.03.016

[6] Briggs, M. A., Bowen, K. J., Kris-Etherton, P. M. (2017). 23 Omega-3 Polyunsaturated Fatty Acids and Health. Food Lipids, 603-626. doi: https://doi.org/10.1201/9781315151854-24

[7] Shahidi, F., Ambigaipalan, P. (2018). Omega-3 Polyunsaturated Fatty Acids and Their Health Benefits. Annual Review of Food Science and Technology, 9 (1), 345-381. doi: https://doi.org/10.1146/annurev-food-111317-095850

[8] Wyness, L., Weichselbaum, E., O’Connor, A., Williams, E. B., Benelam, B., Riley, H., Stanner, S. (2011). Red meat in the diet: an update. Nutrition Bulletin, 36 (1), 34-77. doi: https://doi.org/10.1111/j.1467-3010.2010.01871.x

[9] Li, J., Sun, Q. (2019). Consumption of saturated fatty acids and coronary heart disease risk. International Journal of Cardiology, 279, 27-28. doi: https://doi.org/10.1016/j.ijcard.2019.01.022

[10] Vissers, L. E. T., Rijksen, J., Boer, J. M. A., Verschuren, W. M. M., van der Schouw, Y. T., Sluijs, I. (2018). Fatty acids from dairy and meat and their association with risk of coronary heart disease. European Journal of Nutrition, 58 (7), $2639-2647$. doi: https://doi.org/10.1007/s00394-018-1811-1

[11] Burlingame, B., Nishida, C., Uauy, R., Weisell, R. (Eds.) (2009). Fats and Fatty Acids in Human Nutrition. doi: https://doi.org/ 10.1159/isbn.978-3-8055-9262-8

[12] Lisitsyn, A. B., Chernukha, I. M., Ivankin, A. N. (2013). Comparative study of fatty acid composition of meat material from various animal species. Scientific Journal of Animal Science, 2 (5), 124-131.

[13] Kelly, O., Gilman, J., Ilich, J. (2019). Utilizing Dietary Nutrient Ratios in Nutritional Research: Expanding the Concept of Nutrient Ratios to Macronutrients. Nutrients, 11 (2), 282. doi: https://doi.org/10.3390/nu11020282

[14] Huda, N., Aronal, A. P., Ahmad, R. (2012). Amino Acid and Fatty Acid Profiles of Peking and Muscovy Duck Meat. International Journal of Poultry Science, 11 (3), 229-236. doi: https://doi.org/10.3923/ijps.2012.229.236

[15] Mancini, S., Preziuso, G., Dal Bosco, A., Roscini, V., Parisi, G., Paci, G. (2017). Modifications of fatty acids profile, lipid peroxidation and antioxidant capacity in raw and cooked rabbit burgers added with ginger. Meat Science, 133, $151-158$. doi: https://doi.org/10.1016/j.meatsci.2017.07.003

[16] Papamandjaris, A. A., Macdougall, D. E., Jones, P. J. H. (1998). Medium chain fatty acid metabolism and energy expenditure: Obesity treatment implications. Life Sciences, 62 (14), 1203-1215. doi: https://oi.org/10.1016/s0024-3205(97)01143-0 
[17] Wood, J. D., Richardson, R. I., Nute, G. R., Fisher, A. V., Campo, M. M., Kasapidou, E. et. al. (2004). Effects of fatty acids on meat quality: a review. Meat Science, 66 (1), 21-32. doi: https://doi.org/10.1016/s0309-1740(03)00022-6

[18] Kausar, T., Hanan, E., Ayob, O., Praween, B., Azad, Z. (2019). A review on functional ingredients in red meat products. Bioinformation, 15 (5), 358-363. doi: https://doi.org/10.6026/97320630015358

[19] Falowo, A. B., Fayemi, P. O., Muchenje, V. (2014). Natural antioxidants against lipid-protein oxidative deterioration in meat and meat products: A review. Food Research International, 64, 171-181. doi: https://doi.org/10.1016/j.foodres.2014.06.022

[20] Bozhko, N., Tischenko, V., Pasichnyi, V., Marynin, A., Polumbryk, M. (2017). Analysis of the influence of rosemary and grape seed extracts on oxidation the lipids of peking duck meat. Eastern-European Journal of Enterprise Technologies, 4 (11 (88)), 4-9. doi: https://doi.org/10.15587/1729-4061.2017.108851

[21] Gobert, M., Bourguet, C., Terlouw, C., Deiss, V., Berdeaux, O., Comte, B., Durand, D. (2009). Pre-slaughter stress and lipoperoxidation: protective effect of vitamin $\mathrm{E}$ and plant extracts rich in polyphenols given to finishing cattle. In the Proceedings of the 11th International Symposium on Ruminant Physiology, 814-815.

[22] Moyo, B., Oyedemi, S., Masika, P. J., Muchenje, V. (2012). Polyphenolic content and antioxidant properties of Moringa oleifera leaf extracts and enzymatic activity of liver from goats supplemented with Moringa oleifera leaves/sunflower seed cake. Meat Science, 91 (4), 441-447. doi: https://doi.org/10.1016/j.meatsci.2012.02.029

[23] Nkukwana, T. T., Muchenje, V., Masika, P. J., Hoffman, L. C., Dzama, K., Descalzo, A. M. (2014). Fatty acid composition and oxidative stability of breast meat from broiler chickens supplemented with Moringa oleifera leaf meal over a period of refrigeration. Food Chemistry, 142, 255-261. doi: https://doi.org/10.1016/j.foodchem.2013.07.059

[24] Ahn, J., Grun, I., Mustapha, A. (2007). Effects of plant extracts on microbial growth, color change, and lipid oxidation in cooked beef. Food Microbiology, 24 (1), 7-14. doi: https://doi.org/10.1016/j.fm.2006.04.006

[25] Bozhko, N., Tishchenko, V., Pasichnyi, V., Svyatnenko, R. (2019). Effectiveness of natural plant extracts in the technology of combined meatcontaining breads. Ukrainian Food Journal, 8 (3), 522-531. doi: https://doi.org/10.24263/2304-974x-2019-8-3-9

[26] Pasichnyi, V., Ukrainets, A., Ukrainets, A., Khrapachov, O., Khrapachov, O., Marynin, A. et. al. (2018). Research into efficiency of pasterization of boiled sausage products in order to improve their storage term. Eastern-European Journal of Enterprise Technologies, 6 (11 (96)), 21-28. doi: https://doi.org/10.15587/1729-4061.2018.147946

[27] Fasseas, M. K., Mountzouris, K. C., Tarantilis, P. A., Polissiou, M., Zervas, G. (2008). Antioxidant activity in meat treated with oregano and sage essential oils. Food Chemistry, 106 (3), 1188-1194. doi: https://doi.org/10.1016/j.foodchem.2007.07.060

[28] Karre, L., Lopez, K., Getty, K. J. K. (2013). Natural antioxidants in meat and poultry products. Meat Science, 94 (2), $220-227$. doi: https://doi.org/10.1016/j.meatsci.2013.01.007

[29] Carpenter, R., O’Grady, M. N., O'Callaghan, Y. C., O’Brien, N. M., Kerry, J. P. (2007). Evaluation of the antioxidant potential of grape seed and bearberry extracts in raw and cooked pork. Meat Science, 76 (4), 604-610. doi: https://doi.org/10.1016/ j.meatsci.2007.01.021

[30] Doolaege, E. H. A., Vossen, E., Raes, K., De Meulenaer, B., Verhé, R., Paelinck, H., De Smet, S. (2012). Effect of rosemary extract dose on lipid oxidation, colour stability and antioxidant concentrations, in reduced nitrite liver pâtés. Meat Science, 90 (4), 925-931. doi: https://doi.org/10.1016/j.meatsci.2011.11.034

[31] Umaraw, P., Chauhan, G., Mendiratta, S. K., Verma, A. K., Arya, A. (2020). Effect of oregano and bay as natural preservatives in meat bread for extension of storage stability at ambient temperature. Journal of Food Processing and Preservation, 44 (4). doi: https://doi.org/10.1111/jfpp.14375

[32] Rather, S. A., Masoodi, F. A., Akhter, R., Rather, J. A., Shiekh, K. A. (2016). Advances in use of natural antioxidants as food additives for improving the oxidative stability of meat Products. Madridge Journal of Food Technology, 1 (1), 10-17. doi: https://doi.org/10.18689/mjft-1000102

[33] Ukrainets, A. I., Pasichny, V. M., Zheludenko, Y. V. (2016). Antioxidant plant extracts in the meat processing industry. Biotechnologia Acta, 9 (2), 19-27. doi: https://doi.org/10.15407/biotech9.02.019

[34] Bozhko, N., Tishchenko, V., Pasichniy, V., Verteleckaja, N. (2018). Development of sausages from the peking duck meat. Prohresyvni tekhnika ta tekhnolohiyi kharchovykh vyrobnytstv restorannoho hospodarstva i torhivli, 1 (27), 112-122.

[35] Bozhko, N., Tischenko, V., Pasichnyi, V., Moroz, O. (2019). Research of nutritional and biological value of the semi smoked meatcontaining sausage. Food Science and Technology, 13 (4), 96-103. doi: https://doi.org/10.15673/fst.v13i4.1561

[36] Bozhko, N., Tischenko, V., Pasichnyi, V., Marynin, A., Polumbryk, M. (2017). Study of oxidation processes in duck meat with application of rosemary and grape seed extracts. EUREKA: Life Sciences, 4, 10-15. doi: https://doi.org/10.21303/25045695.2017.00374

[37] Biswas, S., Banerjee, R., Bhattacharyya, D., Patra, G., Das, A. K., Das, S. K. (2019). Technological investigation into duck meat and its products - a potential alternative to chicken. World's Poultry Science Journal, 75 (4), 609-620. doi: https:// doi.org/10.1017/s004393391900062x 
[38] Baéza, E. (2006). Effects of genotype, age and nutrition on intramuscular lipids and meat quality. Proceedings of the 2006 Symposium COA/INRA Scientific Cooperation in Agriculture. Tainan, Tainan, 79-82. Available at: http://www.angrin.tlri. gov.tw/\%5C/INRA/o5.pdf

[39] Ali, M. S., Kang, G.-H., Yang, H.-S., Jeong, J.-Y., Hwang, Y.-H., Park, G.-B., Joo, S.-T. (2007). A Comparison of Meat Characteristics between Duck and Chicken Breast. Asian-Australasian Journal of Animal Sciences, 20 (6), 1002-1006. doi: https:// doi.org/10.5713/ajas.2007.1002

[40] Chartrin, P., Méteau, K., Juin, H., Bernadet, M. D., Guy, G., Larzul, C. et. al. (2006). Effects of Intramuscular Fat Levels on Sensory Characteristics of Duck Breast Meat. Poultry Science, 85 (5), 914-922. doi: https://doi.org/10.1093/ps/85.5.914

[41] Stender, S., Astrup, A., Dyerberg, J. (2012). A trans European Union difference in the decline intransfatty acids in popular foods: a market basket investigation. BMJ Open, 2 (5), e000859. doi: https://doi.org/10.1136/bmjopen-2012-000859

[42] Gayet-Boyer, C., Tenenhaus-Aziza, F., Prunet, C., Marmonier, C., Malpuech-Brugère, C., Lamarche, B., Chardigny, J.-M. (2014). Is there a linear relationship between the dose of ruminant trans-fatty acids and cardiovascular risk markers in healthy subjects: results from a systematic review and meta-regression of randomised clinical trials. British Journal of Nutrition, 112 (12), 1914-1922. doi: https://doi.org/10.1017/s0007114514002578

[43] De Souza, R. J., Mente, A., Maroleanu, A., Cozma, A. I., Ha, V., Kishibe, T. et. al. (2015). Intake of saturated and trans unsaturated fatty acids and risk of all cause mortality, cardiovascular disease, and type 2 diabetes: systematic review and meta-analysis of observational studies. BMJ, h3978. doi: https://doi.org/10.1136/bmj.h3978

[44] Fernández-Ginés, J. M., Fernández-López, J., Sayas-Barberá, E., Pérez-Alvarez, J. A. (2005). Meat Products as Functional Foods: A Review. Journal of Food Science, 70 (2), R37-R43. doi: https://doi.org/10.1111/j.1365-2621.2005.tb07110.x

[45] Remacle, C., Reusens, B. (Eds.) (2004). Functional foods, ageing and degenerative disease. Woodhead Publishing, 792. doi: https://doi.org/10.1533/9781855739017

[46] Movileanu, I., Núñez de González, M. T., Hafley, B., Miller, R. K., Keeton, J. T. (2013). Comparison of Dried Plum Puree, Rosemary Extract, and BHA/BHT as Antioxidants in Irradiated Ground Beef Patties. International Journal of Food Science, 2013, 1-7. doi: https://doi.org/10.1155/2013/360732

[47] Shah, M. A., Bosco, S. J. D., Mir, S. A. (2014). Plant extracts as natural antioxidants in meat and meat products. Meat Science, 98 (1), 21-33. doi: https://doi.org/10.1016/j.meatsci.2014.03.020

[48] Domínguez, R., Pateiro, M., Gagaoua, M., Barba, F. J., Zhang, W., Lorenzo, J. M. (2019). A Comprehensive Review on Lipid Oxidation in Meat and Meat Products. Antioxidants, 8 (10), 429. doi: https://doi.org/10.3390/antiox8100429 